\author{
KINGA KUSZAK \\ Uniwersytet im. Adama Mickiewicza \\ $w$ Poznaniu
}

\title{
DZIECKO W KONWENCJI ROLI - ASPEKT WERBALNY
}

\begin{abstract}
Kuszak Kinga, Dziecko w konwencji roli - aspekt werbalny [Child in the Role Convention the Verbal Aspect]. Studia Edukacyjne nr 37, 2015, Poznań 2015, pp. 47-59. Adam Mickiewicz University Press. ISBN 978-83-232-2967-4. ISSN 1233-6688. DOI: 10.14746/se.2015.37.4

The article describes Erving Goffman's approach to the concept of a dramaturgical model of social relations. The author briefly presents the general framework of the concept (stage, actors, role convention, mask, audience, etc.), focusing in more detail on the verbal aspect of a social role. She highlights the way children, through participation in interactions with parents, preschool teachers and peers, master the rules of various social roles and transpose the experiences gained through these interactions into other social situations, e.g. transposing the rules of linguistic politeness mastered in preschool into the home environment, using specific linguistic means to influence other members of the household. Theoretical reflections are illustrated with examples of preschool-aged children's utterances indicating their mastery of the specific features of a given role. In the last part of the article, the author presents examples of children transgressing the convention of a role, which are a result of either the children's lack of knowledge about the convention or their conscious action against adults' expectations and attempts to manifest their own independence or verify to what extent the convention is of a universal nature and to what extent it can be modified.
\end{abstract}

Key words: Erving Goffman's concept, dramaturgical model of social relations, preschool-aged child in social relations, communicative competence, child's communication with adults and peers

\section{Wprowadzenie}

Erving Goffman ${ }^{1}$ opisując relacje komunikacyjne między ludźmi, posłużył się metaforą teatru i przyjął perspektywę dramaturgiczną dla wyjaśniania specyfiki interakcji społecznych. Założył on, że relacje społeczne polegają

${ }^{1}$ E. Goffman, Człowiek w teatrze życia codziennego, Warszawa 1981. 
na pewnych powtarzalnych interakcjach, ujętych $\mathrm{w}$ konwencję teatralną. Wyróżnił następujące jej elementy: aktor, rola, widownia (publiczność), występ, miejsce (scena), dekoracja, kulisy. Zauważył, iż „matryca możliwych zdarzeń oraz sieć ról, których zetknięcie prowadzi do określonego zdarzenia, razem wyznaczają obszar brzemiennej w skutki akcji dramatu"2. Zdaniem Goffmana, człowiek podejmuje różne role zależnie od sytuacji, etapu $\mathrm{w}$ indywidualnej drodze rozwoju, wcześniejszych doświadczeń życiowych. Niektóre wybiera sam, inne zostają mu narzucone przez reguły życia społecznego. Grając, próbuje sprawić, żeby inni uznali go za takiego, jakim przedstawia się $\mathrm{w}$ przyjętej roli (rolach), dążąc jednocześnie do tego, by oddziaływać na innych i realizować osobiste cele.

\section{Koncepcja roli w dramaturgicznym modelu Ervinga Goffmana}

Rola jest działaniem jednostki (aktora) w określonej przestrzeni/miejscu zwanym sceną $\mathrm{w}$ obecności widowni (publiczności), zgodnie z przyjętymi zasadami, normami jej pełnienia. Jak podkreśla E. Goffman,

odgrywanie roli przez jednostkę polega w dużej mierze na szeregu spotkań twarzą w twarz z partnerem roli (role others), a więc istotnymi adresatami działań (audiences) ${ }^{3}$. Wymaga zachowania konwencji określającej, jakich sytuacji, zachowań, komunikatów należy unikać, a jakie są w danej sytuacji pożądane, gdyż pozwalają na „zachowanie twarzy"4.

Podjęcie roli pociąga więc wiele działań wpisanych w jej specyfikę, które jednostka musi opanować i konsekwentnie zrealizować. Występ natomiast jest "aranżacją, która przekształca jednostkę w wykonawcę scenicznego" 5 . Jest też, jak zauważa autor analizowanej koncepcji,

publicznym wyrazem odnowienia i potwierdzenia wartości moralnych, do których jednostka należy. Jeżeli jednostka nauczy się posługiwać właściwym zespołem zna-

2 E. Goffman, Rozrywka w grach, [w:] Wspótczesne teorie socjologiczne, t. I, red. I. Borowik, J. Mucha, Kraków 2015, s. 44.

${ }^{3}$ E. Goffman, Spotkania, Kraków 2010, s. 68.

4 Pod pojęciem "twarzy” E. Goffman rozumie „pozytywną wartość społeczną przypisywaną osobie $\mathrm{w}$ danej sytuacji spotkania, gdy inni przyjmują, że trzyma się określonej roli" (E. Goffman, Rytuat interakcyjny, Warszawa 2006, s. 5).

${ }^{5}$ E. Goffman, Analiza ramowa, Kraków 2010, s. 97. 
ków/symboli, będzie mogła je wykorzystać w celu upiększenia swoich codziennych występów i nadawania im cenionego w społeczeństwie stylu' ${ }^{6}$.

Realizacja określonych zadań, wynikających z przepisu roli, które są akceptowane przez grupę, spotyka się z pozytywnym odbiorem (aprobatą) odbiorców (widowni). Aktorzy ukrywają więc swoje prawdziwe oblicza i starają się „nie wypaść z roli” („nie stracić twarzy”). Pełnienie roli jest zatem rezultatem uruchomienia zachowań konformistycznych, kiedy człowiek „całkowicie akceptuje zarówno społecznie określone cele kulturowe, jak i zinstytucjonalizowane środki ich osiągania ${ }^{7 \prime}$. Rola może jednak być realizowana w sposób innowacyjny, wbrew obowiązującej konwencji. Goffman zauważa bowiem, że podjęcie roli i jej realizacja nie musi być wyłącznie „biernym dopasowywaniem się do jakiejś normy, ponieważ każdy może i jednocześnie stara się pokazać w jak najbardziej korzystnym świetle" 8 . Ta próba uzewnętrznienia siebie może wyrażać się w pewnej niekonwencjonalności, która jednak powinna być realizowana w taki sposób, by przedstawić aktora w możliwie korzystnym świetle. Zgodnie z tezą E. Goffmana,

w obecności innych jednostka z reguły wyposaża swoją działalność w znaki pozwalające dramatycznie oświetlić i wydobyć z cienia przemawiające na jej korzyść fakty, które w innym wypadku mogłyby pozostać niewidoczne lub niezauważone ${ }^{9}$.

W praktyce rola jest wypadkową tego, co aktor chciałby zaprezentować oraz rezultatem oczekiwań stawianych wobec niego przez osoby z jej otoczenia. Najczęściej aktor stara się dbać o to, żeby wrażenie jakie chce wywołać odpowiadało przypisanym tej roli cechom. W „byciu w roli” pomaga zatem przyjęcie i zaakceptowanie zachowań, jakie wyznaczone są jej konwencją; wybrana postać, odpowiadająca jej maska powinny być zaakceptowane i uznane ${ }^{10}$ przez otoczenie. Pod maską należy ukryć pewne stany psychiczne i emocje, gdyż „każdy, kto wchodzi w spotkanie, powinien przybrać obowiązujący w jego ramach nastrój"11. Właściwie założona maska pozwala z kolei oddziaływać na otoczenie i kontrolować je. Nieodłącznym elementem każdej roli jest jej aspekt werbalny - tekst roli, a także sposób, w jaki aktor wygłasza swoje kwestie. Muszą one być zgodne z ogólnie przyjętą konwencją roli.

${ }^{6}$ A. Borowski, Erving Goffman i Michel Foucault - analiza dyskursów, International Letters and Humanistic Sciences, 2013, 1, s. 21.

7 Za: R. Michalak, Dziecko u progu edukacji przedmiotowej, Poznań 2013, s. 29.

${ }^{8}$ Ch. Bylon, X. Mignot, Komunikacja, Kraków 2008, s. 256.

${ }^{9}$ E. Goffman, Człowiek w teatrze życia, s. 69

10 B. Ollivier, Nauki o komunikacji, Warszawa 2010, s. 168.

${ }^{11}$ E. Goffman, Rozrywka w grach, s. 41. 


\section{Werbalny aspekt roli}

Ma on swój początek w konceptualizacji odbiorcy-widza sformułowanej w umyśle nadawcy-aktora. Ważne jest tutaj uzmysłowienie sobie, czego oczekuje drugi człowiek, co wie o rzeczywistości, z jakiej perspektywy ją ogląda itp. Jednostka musi zatem umieć przedstawić sobie wiedzę, myśli, uczucia, pragnienia drugiego człowieka, a więc stworzyć teorię jego umysłu. Powinna też zdawać sprawę z istnienia ogólnych reguł społecznych porządkujących relacje między ludźmi i regulujących funkcjonowanie jednostek w świecie. Mając obraz odbiorcy i świadomość zasad funkcjonowania społecznego, planuje swoją wypowiedź, dobierając wyrazy ze słownika umysłowego tak, aby odpowiadała ona potrzebom widza (adresata) i wpisywała się w specyfikę szerszego kontekstu (kontekstów). Porządkuje słowa i nadaje im formę w sposób zgodny z zasadami wyznaczonymi przez szereg reguł, $\mathrm{w}$ tym reguły gramatyczne, składniowe, morfologiczne, fonologiczne (odzwierciedlające określoną konwencję). Konwencja powinna istnieć oraz być uznana zarówno przez aktora jak i widza (odbiorcę), a okoliczności jej zastosowania muszą być dla niej właściwe ${ }^{12}$. Korzystanie przez uczestników (spektaklu) z podobnych kodów zawartych w procedurze określonych aktów mowy sprawia, że podobnie interpretują sytuacje, w których się znajdują, na temat których się komunikują.

\section{Uczenie się przez dziecko reguł komunikacji werbalnej w roli społecznej}

Dzieciństwo jest etapem, w którym jednostka poznaje podstawowe zasady współtworzenia relacji między ludźmi i opanowuje elementarne konwencje ról społecznych, zaś rola, jak twierdzi E. Goffman, jest „podstawową jednostką socjalizacji. To właśnie za pośrednictwem ról dochodzi do rozdzielenia zadań w społeczeństwie oraz zawarcia ustaleń zmuszających jednostki do ich wykonania"13. Już w drugim roku życia dzieci zaczynają uświadamiać sobie to, że powinny zachowywać się zgodnie z zasadami, które mają charakter norm społecznych, zaczynają tymi standardami się interesować. Sprzyja temu rozwój mowy, co powoduje, że „mogą one werbalizować swoje zainteresowania kwestią standardów i dyskutować o nich"14

12 J.L. Austin, Mówienie i poznanie. Rozprawy i wykłady filozoficzne, Warszawa 1993, s. 317.

${ }^{13}$ E. Goffman, Spotkania, s. 69.

14 Za: H.R. Schaffer, Rozwój społeczny. Dzieciństwo i młodość, Kraków 2006, s. 289. 
z dorosłymi i rówieśnikami. W tym okresie zaczynają wykorzystywać różne typy komunikatów (różne typy aktów mowy), by coraz lepiej komunikować się z ludźmi. Jednostka może więc informować, szukać informacji zadając pytania, formułować polecenia, perswadować. Dzieci wykazują też szereg umiejętności społecznych, które pozwalają im podejmować pierwsze role, jak: rola dziecka - członka rodziny, rola przedszkolaka, rola rówieśnika, w ramach tych ról uczestniczą w epizodach, które wzbogacają ich indywidualne doświadczenia i sprzyjają tworzeniu obrazu ról społecznych. Przedmiotem dalszych rozważań uczynię te właśnie pierwsze role, które podejmuje dziecko, przy tym zwrócę uwagę na wybrane aspekty werbalnej realizacji każdej z nich. Skupię się na pewnych zachowaniach językowych, które dziecko demonstruje w obecności określonego (wyposażonego w narzędzia kontroli społecznej) widza lub uczestnika interakcji, które bez udziału (biernego lub czynnego) drugiego człowieka nie są, lub nie muszą być, uruchamiane. Zwrócę przy tym uwagę, że inne zachowania językowe towarzyszą roli dziecka, inne - roli przedszkolaka, a jeszcze inne - roli rówieśnika.

\section{Rola dziecka - członka rodziny}

$\mathrm{W}$ trakcie wczesnych relacji $\mathrm{w}$ środowisku najbliższych osób dziecko uczy się pełnić rolę dziecka swoich rodziców (opiekunów), członka rodziny. Doświadcza tego, jak należy odgrywać pewne epizody wynikające z roli: epizod osoby mówiącej, adresata, osoby pytającej, perswadującej itp. Rodzice (opiekunowie), a także inni członkowie rodziny, poprzez swoje reakcje na sposób i formę komunikowania się dziecka, dostarczają mu ,językowych narzędzi do interpretowania rzeczywistości oraz uczestniczenia w procesie komunikacji15. Jako aktorzy $\mathrm{w}$ swoich rodzicielskich rolach, ale także jako zaangażowani widzowie odzwierciedlają jednostce to, jaki sposób werbalnego wyrażania danej roli (epizodu) jest właściwy i pożądany. Konsekwentne zaangażowanie $\mathrm{w}$ relację pozwala dziecku zrozumieć specyfikę roli, bez konieczności sankcji ze strony opiekunów. Opiekunowie budują relację sprzyjającą uczeniu się przez dziecko roli. Czynią to posługując się w relacjach z dzieckiem i innymi członkami rodziny odmianą języka, którą określa się mianem języka familijnego ${ }^{16}$. Jego cechą charakterystyczną jest słownictwo z elementami: kolokwializmów, dialektów, regionalizmów, ekspresywizmów, neologizmów, spieszczeń, zgrubien, epitetów, które są świadomie

${ }_{15}$ M. Grochowalska, Rozwijanie umiejętności komunikacyjnych dziecka w przedszkolu, Kraków 2009, s. 38.

${ }^{16}$ K. Handke, Socjologia jezzyka, Warszawa 2009, s. 75 i n. 
lub nieświadomie przyjęte w danej rodzinie ${ }^{17}$ i w sferze językowej odróżniają od innych rodzin. Język familijny uzupełniony przez elementy kodu niewerbalnego i obowiązujące zasady zachowania i interakcji tworzy charakterystyczny dla danej rodziny styl komunikacji. W literaturze wyodrębniono i opisano różne typy stylów (kodów) komunikacyjnych, można tu dla przykładu wymienić: kod ograniczony i rozwinięty według Basila Bernsteina, jednostronny, relacyjny styl komunikacji w ujęciu Johna Stewarta, zaś Lidia Grzesiuk i Ewa Trzebińska wyodrębniły partnerski i niepartnerski sposób komunikacji18, a Ewa Filipiak charakteryzowała styl podmiotowy, przedmiotowo-bierny, przedmiotowo-aktywny ${ }^{19}$. W zależności od "przyjętego" stylu komunikacji, dzieci (już w drugim roku życia ${ }^{20}$ ) nieco inaczej odgrywają swoje role, sięgają do innych środków językowych formułując komunikaty związane $\mathrm{z}^{21}$ :

- pozyskiwaniem i utrzymywaniem uwagi dorosłych w sposób zgodny z przyjętą w rodzinie konwencją roli, np.: "mamusiu, popatrz, popatrz, zobacz, co dla ciebie zrobitem", albo "no, mamo patrz!", "plose stuchać"22;

- nakłanianiem dorosłych do udzielania pomocy: „bo mnie tak dzisiaj bola rączki" lub "ale ja przecież nie umiem”, "proszę, pomóż, tak się bardzo zmęczyłem i nie mam już sity";

- wyrażaniem miłości i wrogości zgodnie z charakterystyką roli: „bo ja cię tak strasznie kocham", "mamusiu kocham cię" lub "nie lubię cię!";

- wyrażaniem niezależności: "mama dlaciedo ty mnie ubielaś? Psiecieś ja umiem siama"23, "nie chcę, ja sam!" lub „nie, ja, ja, ale ja umiem!”.

Umiejętności związane z komunikacją z innymi zdobyte $\mathrm{w}$ kontakcie z rodzicami (opiekunami) mogą sprzyjać lub utrudniać funkcjonowanie jednostki w kolejno podejmowanych rolach. Te pierwsze doświadczenia są jednak kluczowe dla dalszych kontaktów, a następne role realizowane w innych grupach społecznych mogą jedynie modyfikować wcześniej opanowane reguły porozumienia się ${ }^{24}$. Warto zauważyć, że rodzice tworzą oka-

17 Tamże, s. 77.

18 L. Grzesiuk, E. Trzebińska, Jak ludzie porozumiewaja się, Warszawa 1987, s. 137-145.

19 E. Filipiak, Konteksty rozwoju aktywności językowej dzieci w wieku wczesnoszkolnym, Bydgoszcz 2002, s. 2015 i n.

20 Z. Babska, G.W. Shugar, Idea dwupodmiotowości interakcji dorosty-dziecko w procesie wychowania w pierwszych latach $\dot{z} y c i a$, Lublin 1986, s. 24.

21 Trzy pierwsze zdolności społeczne dziecka opisane zostały przez B. White'a, podaję za: A. Twardowski, Wczesne wspomaganie rozwoju dzieci z niepetnosprawnościami w środowisku rodzinnym, Poznań 2014, s. 27; czwarta została przedstawiona w książce K. Kuszak, Dynamika rozwoju samodzielności dziecka w wieku przedszkolnym, Poznań 2006.

22 Za: B. Boniecka, Dziecięce wyobrażenie świata, Lublin 2010, s. 255.

$23 \mathrm{Z}$ wypowiedzi dziewczynki 2 lata 10 miesięcy.

24 S. Grabias, Jezyk w zachowaniach społecznych, Lublin 1997. 
zje, by dzieci pod ich kierunkiem poznawały specyfikę innych ról, rozszerzając przestrzeń komunikacyjną na inne osoby. Te doświadczenia pozwalają dziecku dokonać porównania specyfiki różnych ról25.

\section{Rola przedszkolaka}

Z chwilą podjęcia edukacji przedszkolnej poszerza się przestrzeń społeczna jednostki, co sprzyja nabywaniu przez nią nowych doświadczeń w zakresie komunikacji werbalnej. Dziecko opanowuje nowe formy zachowań językowych. W specyfikę tej roli „wpisane są” konwencjonalia, w szczególności zaś zasady grzeczności językowej. Normy grzecznościowe stanowią wyraz ogólnie przyjętych sądów powinnościowych i są odbiciem przekonań społecznych co do stosowności lub niestosowności określonych komunikatów. Zdaniem S. Grabiasa, formuły grzecznościowe są "gotowym tekstem wydobywanym $\mathrm{z}$ pamięci $\mathrm{w}$ sytuacjach, w których rozmówcy się znaleźli i muszą ustalić reguły przebiegu interakcji" ${ }^{26}$. Każda formuła grzecznościowa „stanowi nośnik kilku komponentów znaczeniowych, które są jej obligatoryjnymi składnikami i pozwalają odczytać oraz budować spójne strategie interakcyjne" 27 . Ich nieprzestrzeganie wiąże się z doświadczaniem presji społecznej, która jest dla jednostki na tyle dotkliwa, że "członkowie grupy z reguły starają się na nią narażać, gdyż grozi to utratą twarzy"28. Grzeczność językowa przez niektórych autorów ujmowana jest w kategoriach gry, sprowadzającej się do przejawiania zachowań, wyrażania komunikatów pożądanych przez odbiorcę, a więc takich, które w intencji mówiącego są miłe (dobre) dla partnera. Grzecznościowa gra, pisze Małgorzata Marcjanik, „to bezustanne interakcje potwierdzające, że partner jest dla nas osobą ważną" ${ }^{29}$. Zdaniem P. Browna i S.G. Levinsonie, istnieją trzy typy grzeczności:

- pozytywna - opierająca się na wyrażaniu solidarności z partnerem komunikacji,

- negatywna - zasadzająca się na niedemonstrowaniu ekspresji,

- przez unik - polegająca na mówieniu nie wprost ${ }^{30}$.

${ }^{25}$ J.L. Collett, What Kind of Mother Am I? Impression Management and the Social Construction of Motherhood, Symbolic Interaction, 2005, 28, 3, s. 331.

26 S. Grabias, Język, poznanie, interakcja, [w:] Język, interakcja, zaburzenia mowy, red. T. Woźniak, A. Domagał, Lublin 2007, s. 371.

27 Tamże.

${ }^{28}$ M. Marcjanik, Polska grzeczność językowa, Kielce 1997, s. 5.

${ }^{29}$ Tamże, s. 8.

${ }^{30}$ M. Marcjanik, Grzeczność w komunikacji językowej, Warszawa 2008, s. 20. 
Od dziecka w roli przedszkolaka w pierwszej kolejności oczekuje się, by opanowało zasady grzeczności negatywnej, czyli by czegoś nie robiło, oraz przyswoiło podstawy grzeczności pozytywnej. Naciski na opanowanie tej pierwszej wiążą się z formułowaniem zakazów, które dotyczą zarówno zachowań werbalnych, jak i niewerbalnych. Do zakazów odnoszących się do funkcjonowania werbalnego można zaliczyć następujące ${ }^{31}$ : „nie wolno obrażać innych", "nie wolno dokuczać innym", "nie wolno kłócić się", ", nie wolno wyzywać”, ,nie wolno rozmawiać podczas jedzenia”, ,"nie wolno pyskować”, „nie wolno rozmawiać, kiedy mówi nauczyciel” itp. Można więc powiedzieć, że nie ma obszaru dziecięcego komunikowania na terenie przedszkola, do którego któryś z nauczycieli nie "doczepiłby” etykietki z napisem „nie wolno", z jakimś "ograniczeniem" 32 . Ta etykieta zostaje odzwierciedlona w wypowiedziach dziecka, które przyswoiło wspomnianą normę: "bo podczas leżakowania, to nie można mówić", "nie wyrażaj się tak przy ludziach", "ty jesteś niegrzeczniuch"33. Z kolei, grzeczność pozytywna, która służy uzyskaniu dobrego nastawienia widza (odbiorcy) do aktora (nadawcy), wyraża się opanowaniem przez dziecko i demonstrowaniem następujących form komunikatów: powitań, pożegnań, podziękowań, próśb, oferowania pomocy, przeprosin. Opanowaniu tej formy grzeczności językowej sprzyja fakt, iż nauczyciele i personel przedszkola uruchamiają szereg działań perswazyjnych, zgodnych z tezą P.G. Zimbardo i M.R. Leippe, iż „w społeczeństwie o zdecydowanie werbalnej kulturze, apele perswazyjne są często najważniejszym instrumentem wywierania wpływu" ${ }^{\prime 2}$. Dziecko jest nakłaniane do zwerbalizowania pożądanego komunikatu w następujący sposób: „powiedz dzień dobry”, "pożegnaj się", "prosze, powiedz: przepraszam”. Działania językowe o charakterze perswazji powodują, że jednostka - przedszkolak zaczyna orientować się $\mathrm{w}$ oczekiwaniach kierowanych $\mathrm{w}$ jej stronę i podejmuje grę zgodną z konwencją. Demonstruje pożądane zachowania, np. wchodzi do sali z głośnym "dzień dobry", wyraża skruchę (czasem wyłącznie w obecności osoby dorosłej, rejestrując jednocześnie jej reakcję) „Prosze pani, ja już powiedziałem przepraszam, no daj ręke na zgodę" lub35:

Chłopiec 1: A pani co tak tu siedzi?

Nauczycielka: Stucham was.

31 Odwołuję się do wyników badań Agnieszki Olczak, W labiryncie dziecięcych potrzeb i nauczycielskich oczekiwań - krótka historia jednego dnia w przedszkolu, [w:] Pedagogika przedszkolna. Oblicza i poszukiwania, red. M. Magda-Adamowicz, A. Olczak, Torun 2014.

32 Tamże, s. 46-48.

33 B. Boniecka, Dziecięce wyobrażenie świata, s. 249-251.

34 P.G. Zimbardo, M.R. Leippe, Psychologia zmiany postaw $i$ wptywu społecznego, Poznań 2004, s. 173.

${ }^{35}$ Rozmowa dwóch chłopców 4-letnich z nauczycielką w przedszkolu. 
Ch 1: Co, stucha nas?

Ch 2: No

Ch 1: To musimy być grzeczni?

$\mathrm{N}$ : Zawsze musicie być grzeczni.

Ch 1: To ja wole tylko dziś, a ty?

Ch 2: To ja też mogę.

Badania M. Shatz i H. Gleitman dowodzą, iż dzieci czteroletnie mają pewną świadomość innych jako słuchaczy i potrafią na jej podstawie modyfikować własną mowę ${ }^{36}$, sposób komunikowania się, co również odzwierciedla powyższy dialog. W związku z tym osiągnięciem rozwojowym zasada dotycząca językowych form przejawiania grzeczności może zostać przeniesiona na relacje z rówieśnikami. Dziecko może (w obecności dorosłego) grać kolejną rolę - "grzecznego dziecka - strażnika konwencji językowej", kierując w stronę innych dzieci komunikaty perswazyjne: "jak pani powie smacznego, to musisz powiedzieć: dziękuje", co wcale nie oznacza internalizacji zasady i jej realizacji w sytuacjach pozaprzedszkolnych. Norma może obowiązywać tylko w tym miejscu, tej sytuacji i być częścią tej właśnie roli. Może jednak regulować zachowanie dziecka w innych sytuacjach, w innych rolach, np. domowych po powrocie z przedszkola:

Dziewczynka37: Przy jedzeniu się nie gada, bo się w brzuszku źle układa.

Mama: A kto cię tego nauczyt?

Dz: Pani w przedszkolu.

M: To ładnie.

Dz: Mamusiu, powiedz mi jeszcze smacznego.

M: Smacznego.

Dz: Dziękujemy, wszystko zjemy, a herbatę wylejemy.

Jak widać, dziecko przenosi na inną rolę doświadczenia językowe zdobyte $\mathrm{w}$ środowisku przedszkolnym, czyni to, aby uzyskać nie tylko uwagę, ale też aprobatę najbliższych.

\section{Rola rówieśnika}

Specyfiką tej roli jest zdobywanie doświadczeń $\mathrm{w}$ relacji z partnerem o podobnym doświadczeniu życiowym i zbliżonej perspektywie postrzegania rzeczywistości. W literaturze podkreśla się, że relacje rówieśnicze - partnerskie sprzyjają rozmowie, dzieleniu się wiedzą, umiejętnościami i w szcze-

36 J.W. Astington, Metapragmatyka: dziecięca koncepcja obiecywania, [w:] Jezzyk dziecka, red.

B. Bokus, G.W. Shugar, Gdańsk 2007, s. 342.

${ }^{37}$ Rozmowa 4-letniej dziewczynki z mamą. 
gólny sposób stymulują do aktywności językowej. W relacji z rówieśnikiem dziecko doświadcza własnego sprawstwa w sferze komunikacji werbalnej. Intuicyjnie rozumiejąc, iż perswazyjna funkcja wypowiedzi polega na „usiłowaniu uzyskania realnego wpływu na sposób myślenia lub postępowania odbiorcy, jednakże nie drogą bezpośredniego rozkazu, lecz metodą utajoną i pośrednią" 38 , dziecko doświadcza poczucia sprawstwa nakłaniając rówieśnika, grożąc mu, obiecując, przymilając się, podnosząc własną atrakcyjność. Odnosząc się do licznej i różnorodnej grupy komunikatów perswazyjnych ${ }^{39}$, chciałabym skoncentrować swoją dalszą wypowiedź wyłącznie na komunikatach ingracjacyjnych, a więc związanych z podnoszeniem własnej atrakcyjności $\mathrm{w}$ relacji $\mathrm{z}$ rówieśnikiem poprzez językowe formy prezentowania siebie. D. Galasiński wśród komunikatów mających na celu prezentację samego siebie wyróżnił następujące (zostaną one zilustrowane wypowiedziami dzieci $\mathrm{w}$ wieku przedszkolnym kierowanymi w stronę rówieśnikó $\left.\mathrm{w}^{40}\right)$ :

- wymienianie własnych cech i właściwości cenionych społecznie bądź pożądanych przez partnera, np.: "no mam, a ja mam w domu gre $i$ wiem, jak się w nia gra"41, "ja to zrobie, bo ja wiem jak to zrobić"42, "ja mam moc Jowisza, bo jest największy"43, "ja już dawno się tego nauczyłem";

- wymienianie siebie jako uczestnika sytuacji, zdarzeń, ról społecznych, które wymagają wspomnianych powyżej cechy i własności np.: "a ja widziatam kiedyś prawdziwego misia, jak byłam z rodzicami w ZOO";

- sugerowanie posiadania potencjalnie cennych dla partnera wartości materialnych czy przedmiotowych i niematerialnych, np.: "a ty nie masz takiego dinozaura", "też mam taki komputer" 44 , "mam nowe kredki, wiesz, ciocia mi kupiła". Ta grupa wypowiedzi wydaje się najliczniejsza, gdyż można je odnotować w większości wypowiedzi w relacjach rówieśniczych;

- sugerowanie partnerowi korzyści płynącej z interakcji z nim, np.: "pożyczę ci mój motor, ale jak ty mi gitarę";

- cytowanie pozytywnych opinii i sądów o sobie: „a ciocia powiedziała, że ja już moge sam";

38 Za: D. Galasiński, Chwalenie sie jako perswazyjny akt mowy, Kraków 1992, s. 15.

${ }^{39}$ Grupa perswazyjnych aktów mowy jest bogata i różnorodna. Zalicza się tu: insynuację, kpinę, szyderstwo, drwinę, ośmieszenie, wypowiedzi propagandowe, wypowiedzi ingracjacyjne: chwalenie się, chwalenie kogoś, pochlebstwo, konformizm, także kazania, nauczanie.

40 Przykłady pochodzą ze zbiorów własnych.

${ }^{41} \mathrm{Z}$ wypowiedzi dziecka 4-letniego.

42 Wypowiedź dziecka 4-letniego.

${ }^{43} \mathrm{Z}$ wypowiedzi dziecka 5-letniego.

${ }^{44} \mathrm{Z}$ wypowiedzi dziecka 3-letniego. 
- wymienianie bądź sugerowanie własnych sukcesów ${ }^{45}$ : "a zobacz, jak tadnie mi wyszto"46, "bo ja to dawno już zrobiłam".

Zaprezentowane tutaj przykłady wypowiedzi dzieci wskazują, że już na tym etapie życia jednostka pełniąc rolę rówieśnika, partnera współdziałania, dokonuje autoprezentacji w taki sposób, aby partner chciał wybrać lub kontynuować kontakty z daną osobą ${ }^{47}$.

\section{Podsumowanie}

Zdaniem E. Turiela48, dzieci stosunkowo wcześnie uczą się rozróżniać dwie kategorie norm społecznych wyznaczających ramy społecznego (także komunikacyjnego) funkcjonowania, do których zalicza się zasady moralne i konwencje. Te pierwsze mają charakter uniwersalny, są wzmacniane przez sankcje społeczne, zaś konwencje (reguły i konwenanse) mające ułatwić relacje między ludźmi, które są np. narzucane przez autorytety, specyfikę ról, obowiązujące praktyki społeczne, nie mają charakteru uniwersalnego ${ }^{4}$. Oznacza to, że w pewnych sytuacjach dopuszcza się możliwość wykroczenia poza konwencję roli. W pewnych sytuacjach dzieci podejmują więc próby odgrywania roli w sposób niezgodny ze scenariuszem:

- przerywając komunikację w sposób nieoczekiwany dla rozmówcy, np.

Przykład 1

Dorosły: Opowiedz mi jeszcze o tym co lubisz robić najbardziej.

Dziecko: Ja nie chce (przerywa komunikację).

Przykład 2

Dorosły: Co lubisz robić, kiedy wracasz z przedszkola do domu?

Dziecko: $O$, Jaś przyszedt, cześć Jasiu (ignoruje rozmówcę).

- nawiązując komunikację z sposób niezgodny ze specyfiką roli

Przykład:

Dorosły: Jestem Kasia, a ty jak masz na imię?

Dziecko: (podając dorosłemu maskotkę-tygryska) Jestem tygrysek, przywitaj się z tygryskiem.

45 D. Galasiński, Chwalenie się, s. 31.

${ }^{46}$ Wypowiedź 4-letniego chłopca do kolegi podczas zajęć plastycznych.

${ }^{47}$ Za M. Rudy-Muża, Internetowe lustro autoprezentacji, Toruń 2011, s. 76.

48 Podaję za H.R. Schafferem, Rozwój społeczny, s. 299.

${ }^{49}$ S. Fullart, Distinguishing Morality form Convention: Evidence for Nativism, Journal of Cognition and Neuroethics, 2013, 1, s. 8. 
Takie zachowania wskazują, że dziecko nie chce podjąć roli zgodnie ze scenariuszem zaproponowanym (narzuconym) przez dorosłego. Mogą też sugerować, że nie potrafi odczytać specyfiki roli i nie może odegrać jej zgodnie z oczekiwaniami społecznymi. Zachowania tego typu mogą też być rezultatem dziecięcych dążeń do wyznaczenia własnych granic, manifestowania własnej niezależności lub zweryfikowania, na ile konwencja ma charakter uniwersalny, a w jakim stopniu można ją zmodyfikować wprowadzając nowe elementy do obowiązującego "przepisu” roli. Jak zauważył E. Goffman, jednostki nie są pasywne podczas relacji z innymi ludźmi, a każda sytuacja jest wynikiem ich wzajemnego oddziaływania na siebie ${ }^{50}$. Możliwość modyfikacji zachowań i komunikatów werbalnych (zależnie od reakcji otoczenia $\mathrm{w}$ formie przyzwolenia na zmianę konwencji lub „przywołania dziecka do porządku") stanowi dla jednostki cenne doświadczenie społeczne. $\mathrm{W}$ ten sposób dziecko konstruuje pierwotne ramy interpretacyjne, dzięki którym może zrozumieć zdarzenia, w których uczestniczy i podejmować „działania kierowane" 51 przez siebie.

\section{BIBLIOGRAFIA}

Astington J.W., Metapragmatyka: dziecięca koncepcja obiecywania, [w:] Jezzyk dziecka, red. B. Bokus, G.W. Shugar, Gdańskie Wydawnictwo Psychologiczne, Gdańsk 2007.

Austin J.L., Mówienie i poznanie. Rozprawy i wykłady filozoficzne, PWN, Warszawa 1993.

Babska Z., Shugar G.W., Idea dwupodmiotowości interakcji dorosty-dziecko w procesie wychowania w pierwszych latach życia, Uniwersytet Lubelski, Lublin 1986.

Boniecka B., Dziecięce wyobrażenie świata, Wydawnictwo UMCS, Lublin 2010.

Borowski A., Erving Goffman i Michel Foucault - analiza dyskursów, International Letters and Humanistic Sciences, 2013, 1.

Bylon Ch., Mignot X., Komunikacja, Flair, Kraków 2008.

Collett J.L., What Kind of Mother Am I? Impression Management and the Social Construction of Motherhood, Symbolic Interaction, 2005, 28, 3.

Filipiak E., Konteksty rozwoju aktywności językowej dzieci w wieku wczesnoszkolnym, Wydawnictwo AB, Bydgoszcz 2002.

Fullart S., Distinguishing Morality form Convention: Evidence for Nativism, Journal of Cognition and Neuroethics, 2013, 1.

Galasiński D., Chwalenie się jako perswazyjny akt mowy, Wydawnictwo UJ, Kraków 1992.

Goffman E., Response Cries, Language, 1978, 54, 4.

Goffman E., Człowiek w teatrze życia codziennego, PWN, Warszawa 1981.

Goffman E., Rytuat interakcyjny, Wydawnictwo Naukowe PWN, Warszawa 2006.

50 E. Goffman, Cztowiek w teatrze życia, s. 40-44.

${ }^{51}$ E. Goffman, Pierwotne ramy interpretacji, [w:] Wspótczesne teorie socjologiczne, red. A. Jasińska-Kania, L.M. Nijakowski, J. Szacki, M. Ziółkowski, Warszawa 2006, s. 337. 
Goffman E., Pierwotne ramy interpretacji, [w:] Wspótczesne teorie socjologiczne, red. A. Jasińska-Kania, L.M. Nijakowski, J. Szacki, M. Ziółkowski, Wydawnictwo Naukowe Scholar, Warszawa 2006.

Goffman E., Analiza ramowa, Zakład Wydawniczy Nomos, Kraków 2010.

Goffman E., Spotkania, Zakład Wydawniczy Nomos, Kraków 2010.

Goffman E., Relacje w przestrzeni publicznej, Wydawnictwo Naukowe PWN, Warszawa 2011.

Goffman E., Rozrywka w grach, [w:] Wspótczesne teorie socjologiczne, t. I, red. I. Borowik, J. Mucha, Zakład Wydawniczy Nomos, Kraków 2015.

Grabias S., Jezyk w zachowaniach społecznych, Wydawnictwo UMCS, Lublin 1997.

Grabias S., Język, poznanie, interakcja, [w:] Język, interakcja, zaburzenia mowy, red. T. Woźniak, A. Domagał, Wydawnictwo UMCS, Lublin 2007.

Grochowalska M., Rozwijanie umiejętności komunikacyjnych dziecka w przedszkolu, Uniwersytet Pedagogiczny, Kraków 2009.

Grzesiuk L., Trzebińska E., Jak ludzie porozumiewają się, Nasza Księgarnia, Warszawa 1987.

Handke K., Socjologia jezzyka, Wydawnictwo Naukowe PWN, Warszawa 2009.

Kuszak K., Dynamika rozwoju samodzielności dziecka w wieku przedszkolnym, Wydawnictwo Naukowe UAM, Poznań 2006.

Kuszak K., Kompetencje komunikacyjne dzieci w okresie późnego dzieciństwa w aspekcie rozwojowym, Wydawnictwo Naukowe UAM, Poznań 2011.

Marcjanik M., Polska grzeczność językowa, Wyższa Szkoła Pedagogiczna, Kielce 1997.

Marcjanik M., Grzeczność w komunikacji językowej, Wydawnictwo Naukowe PWN, Warszawa 2008.

Michalak R., Dziecko u progu edukacji przedmiotowej, Wydawnictwo Naukowe UAM, Poznań 2013.

Olczak A., W labiryncie dziecięcych potrzeb i nauczycielskich oczekiwań - krótka historia jednego dnia w przedszkolu, [w:] Pedagogika przedszkolna. Oblicza i poszukiwania, red. M. MagdaAdamowicz, A. Olczak, Wydawnictwo Adam Marszałek, Torun 2014.

Ollivier B., Nauki o komunikacji, Oficyna Naukowa, Warszawa 2010.

Retter H., Komunikacja codzienna w praktyce, Gdańskie Wydawnictwo Psychologiczne, Gdańsk 2005.

Rudy-Muża M., Internetowe lustro autoprezentacji, Wydawnictwo Adam Marszałek, Toruń 2011.

Schaffer H.R., Rozwój społeczny. Dzieciństwo i młodość, Wydawnictwo UJ, Kraków 2006.

Twardowski A., Wczesne wspomaganie rozwoju dzieci z niepetnosprawnościami w środowisku rodzinnym, Wydawnictwo Naukowe UAM, Poznań 2014.

Zimbardo P.G., Leippe M.R., Psychologia zmiany postaw i wptywu społecznego, Wydawnictwo Zysk i S-ka, Poznań 2004. 